\title{
Insolvency Risk. Application of Altman Z-score to the auto parts sector in Romania
}

\author{
${ }^{1}$ Ph.D. Student Rodica Baciu (Boanta), ${ }^{2}$ Ph.D. Professor Brezeanu Petre, ${ }^{3}$ Ph. D Lecturer \\ Adrian Simon \\ 1,2 The Bucharest University of Economic Studies Department of Finance School \\ 3 "George Emil Palade" University of Medicine, Pharmacy, Science and Tech. of Târgu Mureș
}

\begin{abstract}
This paper intends to apply the Altman Z-score model to all the companies active in the wholesale of motor vehicle parts and accessories (NACE 4531), with extended financial statements. Using the panel data model over the time series for 2008-2016 on the companies of this sector, we conclude that $99 \%$ of the $Z$-score is explained by the independent variables (working capital, capital structure, turnover, earnings before interest and tax), with estimated parameters very close to the models classical values.

The sample description of the paper and the corresponding results highlights the Z-score evolution by turnover clusters and principal components, with the largest companies performing the best (the only cluster with Z-score median above 3 ). We notice a tendency for decreasing high risk companies and increase in the medium risk companies, whereas the low risk companies are relatively stable. This improvement is mostly due to increasing capitalization rate and less external debt, despite the deteriorating working capital and operating margin.
\end{abstract}

We believe that future research to evaluate Z-score sensitivity under stress test scenarios would be very useful to provide an insight of companies' insolvency risk amid increasing interest rates and different fiscal tax on dividend.

Keywords: Insolvency risk, Altman Z-score , Third keyword, Corporate finance, Econometrics.

\section{Introduction}

New York University Finance Professor Edward Altman, developed the Altman Z-score formula in 1967, later published in 1968. The model is a quantitative balance-sheet and income statement method of determining a company's financial health. A Z-score can be calculated for all non-financial companies and the lower the score, the greater the risk of the company falling into financial distress. The original research was based on data from publicly held manufacturers ( 66 firms, half of which had filed for bankruptcy). Altman calculated 22 common financial ratios for all of them and then used multiple discriminant analysis to choose a small number of those ratios that could best distinguish between a bankrupt firm 
and a healthy one (Altman, 2000). The Altman Z-score model is a multiple regression analysis with the following variables:

$\mathrm{Z}=1.2 * \mathrm{X} 1+1.4 * \mathrm{X} 2+3.3 * \mathrm{X} 3+0.6 * \mathrm{X} 4+1.0 * \mathrm{X} 5$

\begin{tabular}{|c|c|c|}
\hline$x_{1}$ & $\begin{array}{l}\text { Working Capital/ } \\
\text { Assets }\end{array}$ & $\begin{array}{l}\text { Reflects liquidity. A very low proportion of the working capital } \\
\text { (especially negative values for more than } 3 \text { consecutive years) } \\
\text { in total assets may raise funding problems for the company } \\
\text { (Chouhan et al., 2014). Nevertheless, positive working capital } \\
\text { doesn't always reflect strong internal financing capacity, if } \\
\text { receivables and inventories are not monetized (Iqbal and } \\
\text { Zhuquan, 2015). For example, very lengthy collection period of } \\
\text { receivables exposes the subject company to clients default and } \\
\text { systemic risk. According to Singhania and Mehta, 2017, the } \\
\text { more inventories the company is holding, the higher the } \\
\text { exposure to market value volatility risk, short term liquidities } \\
\text { pressures and operational risks (depositing conditions and } \\
\text { insurance costs). }\end{array}$ \\
\hline$x_{2}$ & $\begin{array}{l}\text { Retained Earnings / } \\
\text { Assets }\end{array}$ & $\begin{array}{l}\text { Reflects reserves and investment strategy of the company. } \\
\text { Lower or decreasing values of reported results (figure on } \\
\text { balance, the equity component) may indicate a decreasing } \\
\text { trend of the profits, reserves erosion due to recent year's losses } \\
\text { or increasing dividend distribution (Koussis et al., 2017). Under } \\
\text { this situations, the subject company exposure to external debt } \\
\text { is increasing, making it more vulnerable to fluctuations of } \\
\text { external financing conditions (Royer, 2017). }\end{array}$ \\
\hline$x_{3}$ & $\begin{array}{l}\text { Earnings Before } \\
\text { Interest and Tax / } \\
\text { Assets }\end{array}$ & $\begin{array}{l}\text { Reflects the operating result and efficiency of using the assets } \\
\text { to generate operating income. Lower values for several } \\
\text { consecutive years may indicate a deterioration of the result } \\
\text { from ordinary activities (basic) of the company. According to } \\
\text { Khajavi and Ghoohestani, 2015, this might be caused by lower } \\
\text { gross margin (due to pressure from suppliers or clients) or } \\
\text { higher operational costs (due to average salary increase or } \\
\text { higher costs with fuel and energy). The higher the operating } \\
\text { margin the more value added is generated by the company, } \\
\text { reducing thus the risk of insolvency (Tian and Yu, 2017). }\end{array}$ \\
\hline$x_{4}$ & $\begin{array}{l}\text { Shareholders' equity/ } \\
\text { Debt }\end{array}$ & $\begin{array}{l}\text { Reflects the structure of financing and self-financing ability of } \\
\text { the company (Turner, 2016). Lower values indicate high } \\
\text { dependence on external funding and reduced perspectives of } \\
\text { additional funding. Indeed, increasing debt in the first stage will } \\
\text { lower the weighted average cost of capital (due to tax savings } \\
\text { provided by interest bearing debt). Nevertheless, if the } \\
\text { company becomes over indebted, that will increase the financial } \\
\text { burden, jeopardize business partnerships with suppliers or } \\
\text { clients and increase the risk of insolvency (Wu et al., 2017). }\end{array}$ \\
\hline$x_{5}$ & Turnover/ Assets & $\begin{array}{l}\text { How effectively the company uses its assets to generate } \\
\text { income. The value is recommended to be close to the industry } \\
\text { average. Low levels may indicate that too much capital is } \\
\text { locked in assets. High values may indicate that the company } \\
\text { has too few assets for the potential sales level. }\end{array}$ \\
\hline
\end{tabular}

Interpretation of results:

$Z<1,80=>$ high probability of insolvency;

$1,80<Z<3=>$ medium probability of insolvency;

$Z>3=>$ low probability of insolvency. 


\section{Problem Statement}

The Altman Z-score model is applied to all the companies active in the wholesale of motor vehicle parts and accessories, NACE 4531, with extended financial statements submitted for the entire appraised period were taken into consideration (to eliminate the survivorship effect). Since we need extended format of the financial statements, only companies with turnover above 1 mil EUR have been included, resulting a total number of 168 companies. As illustrated in the next two tables, we observe a large concentration of revenues among the companies with turnover above 5 mil EUR, the latter weigthing almost $80 \%$ from value (revenues perspective) in the total sample of companies.

Table 1: Number distribution of companies

\begin{tabular}{|l|l|l|l|l|l|}
\hline $\begin{array}{l}\text { Year } / \\
\text { Number }\end{array}$ & $\begin{array}{l}1.1-2 \text { mil } \\
\text { EUR }\end{array}$ & $\begin{array}{l}2.2-3 \text { mil } \\
\text { EUR }\end{array}$ & $\begin{array}{l}3.3-5 \text { mil } \\
\text { EUR }\end{array}$ & $\begin{array}{l}4 .+5 \\
\text { mil EUR }\end{array}$ & $\begin{array}{l}\text { Notal } \\
\text { Number }\end{array}$ \\
\hline 2008 & 82 & 29 & 20 & 37 & 168 \\
\hline 2009 & 87 & 29 & 17 & 35 & 168 \\
\hline 2011 & 73 & 27 & 19 & 38 & 168 \\
\hline 2012 & 70 & 34 & 28 & 36 & 168 \\
\hline 2013 & 74 & 35 & 26 & 33 & 168 \\
\hline 2014 & 80 & 24 & 26 & 38 & 168 \\
\hline 2015 & 70 & 32 & 24 & 42 & 168 \\
\hline 2016 & 65 & 31 & 29 & 43 & 168 \\
\hline
\end{tabular}

Table 2: Turnover distribution of companies

\begin{tabular}{|l|l|l|l|l|c|}
\hline $\begin{array}{l}\text { Year / Turnover } \\
\text { (bn RON) }\end{array}$ & $\begin{array}{l}1.1-2 \\
\text { mil EUR }\end{array}$ & $\begin{array}{l}2.2-3 \\
\text { mil EUR }\end{array}$ & $\begin{array}{l}3.3-5 \\
\text { mil EUR }\end{array}$ & $\begin{array}{l}4 .+5 \\
\text { mil EUR }\end{array}$ & Total \\
\hline 2008 & 0.33 & 0.32 & 0.35 & 4.14 & 5.16 \\
\hline 2009 & 0.37 & 0.32 & 0.28 & 3.82 & 4.79 \\
\hline 2010 & 0.41 & 0.32 & 0.31 & 4.14 & 5.18 \\
\hline 2011 & 0.39 & 0.30 & 0.54 & 4.57 & 5.81 \\
\hline 2012 & 0.38 & 0.37 & 0.49 & 4.63 & 5.88 \\
\hline 2013 & 0.41 & 0.40 & 0.46 & 5.14 & 6.40 \\
\hline
\end{tabular}


Ph.D. Student Rodica Baciu (Boanta), 2 Ph.D. Professor Brezeanu Petre, 3 Ph. D Lecturer Adrian Simon Insolvency Risk. Application of Altman Z-score to the auto parts sector in Romania

\begin{tabular}{|l|l|l|l|l|l|}
2014 & 0.48 & 0.26 & 0.44 & 5.51 & 6.69 \\
\hline 2015 & 0.42 & 0.35 & 0.41 & 5.64 & 6.82 \\
\hline 2016 & 0.40 & 0.35 & 0.49 & 5.73 & 6.98 \\
\hline
\end{tabular}

Source: Ministry of finance, data processed by the author

The sample is reflecting a general challenge of the business environment in Romania, related to the increasing polarization of revenues. As observed in right table, the largest 1.000 companies active in Romania weight almost $50 \%$ from the total revenues generated by all companies during 2016 , as compared to a $35 \%$ concentration during 2008. This is narrowing the middle layer business and lowering the overall competitiveness of companies.
Tabel 3: Revenues of top 1.000 companies in Romania

\begin{tabular}{l|l|l} 
Year & Turnover (bn RON) & Weight in total
\end{tabular}

\begin{tabular}{|l|l|l|}
\hline 2008 & 323 & $35 \%$ \\
\hline 2009 & 295 & $34 \%$ \\
\hline 2010 & 355 & $39 \%$ \\
\hline 2011 & 438 & $44 \%$ \\
\hline 2012 & 478 & $45 \%$ \\
\hline 2013 & 501 & $48 \%$ \\
\hline 2014 & 532 & $48 \%$ \\
\hline 2015 & 567 & $49 \%$ \\
\hline 2016 & 623 & $50 \%$ \\
\hline
\end{tabular}

Source: Ministry of finance, data processed by the author

Given the overall concentration of revenues among the largest companies in the overall business environment and the selected list of companies, the sample is divided in four different clusters by turnover level, that will further represent the cross-sectional series in the panel data model described in the methodology. The following table and graph illustrate the results of Altman Z-score applied to the sample of companies active in the wholesale of motor vehicle parts and accessories (NACE 4531). The Z-score for the 168 companies is computed for the entire appraised period (2008-2016) and the evolution illustrates a tendency for decreasing high risk companies (from 25 in 2008 down to 15 in 2016) and increase in the medium risk companies (from 43 in 2008 to 56 in 2016), whereas the low risk companies are relatively stable.

Table 4: Altman Z-score distribution Graph1: Risk distribution by Z-score 
Ph.D. Student Rodica Baciu (Boanta), 2 Ph.D. Professor Brezeanu Petre, 3 Ph. D Lecturer Adrian Simon Insolvency Risk. Application of Altman Z-score to the auto parts sector in Romania

\begin{tabular}{|l|l|l|l|}
\hline Year & $\begin{array}{l}\text { High } \\
\text { Risk }\end{array}$ & $\begin{array}{l}\text { Medium } \\
\text { Risk }\end{array}$ & $\begin{array}{l}\text { Low } \\
\text { Risk }\end{array}$ \\
\hline 2008 & 25 & 43 & 100 \\
\hline 2009 & 28 & 50 & 90 \\
\hline 2010 & 19 & 54 & 95 \\
\hline 2011 & 17 & 46 & 105 \\
\hline 2012 & 26 & 46 & 96 \\
\hline 2013 & 23 & 40 & 105 \\
\hline 2014 & 21 & 46 & 101 \\
\hline 2015 & 21 & 41 & 106 \\
\hline 2016 & 15 & 56 & 97 \\
\hline
\end{tabular}

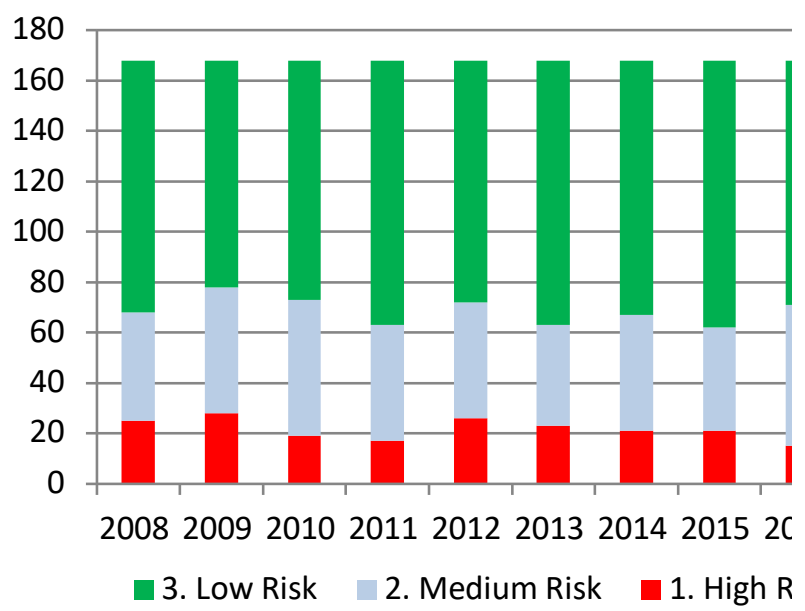

Source: data processed by the author

Next, the Z-score median is computed for all the selected companies by different cluster. As illustrated in the next table and graph, the overall Z-score has marginally decreased for most of the clusters, with the largest companies ( +5 mil EUR turnover) performing the best according the Altman Z-score (median value above 3 ).

Table 5: Z-score distribution by turnover

\begin{tabular}{|c|c|c|c|c|c|}
\hline $\begin{array}{l}\text { Year / } \\
\text { Z- } \\
\text { Median } \\
\text { Value }\end{array}$ & $\begin{array}{l}1-2 \\
\text { mil } \\
\text { EUR }\end{array}$ & $\begin{array}{l}2-3 \\
\text { mil } \\
\text { EUR }\end{array}$ & $\begin{array}{l}3-5 \\
\text { mil } \\
\text { EUR }\end{array}$ & $\begin{array}{l}+5 \\
\mathrm{mil} \\
\mathrm{EU} \\
\mathrm{R}\end{array}$ & $\begin{array}{l}\text { Tota } \\
\text { I }\end{array}$ \\
\hline 2008 & 2.84 & 3.18 & 3.32 & $\begin{array}{l}3.3 \\
4\end{array}$ & 3.28 \\
\hline 2009 & 2.76 & 3.34 & 2.52 & $\begin{array}{l}3.2 \\
8\end{array}$ & 3.17 \\
\hline 2010 & 2.66 & 3.29 & 3.34 & $\begin{array}{l}3.3 \\
8\end{array}$ & 3.28 \\
\hline 2011 & 2.78 & 3.16 & 3.05 & $\begin{array}{l}3.0 \\
1\end{array}$ & 2.99 \\
\hline 2012 & 2.24 & 3.16 & 3.41 & $\begin{array}{l}2.2 \\
0\end{array}$ & 2.35 \\
\hline 2013 & 2.54 & 2.55 & 3.55 & $\begin{array}{l}2.6 \\
3\end{array}$ & 2.66 \\
\hline
\end{tabular}

Graph 2: Z-score median values

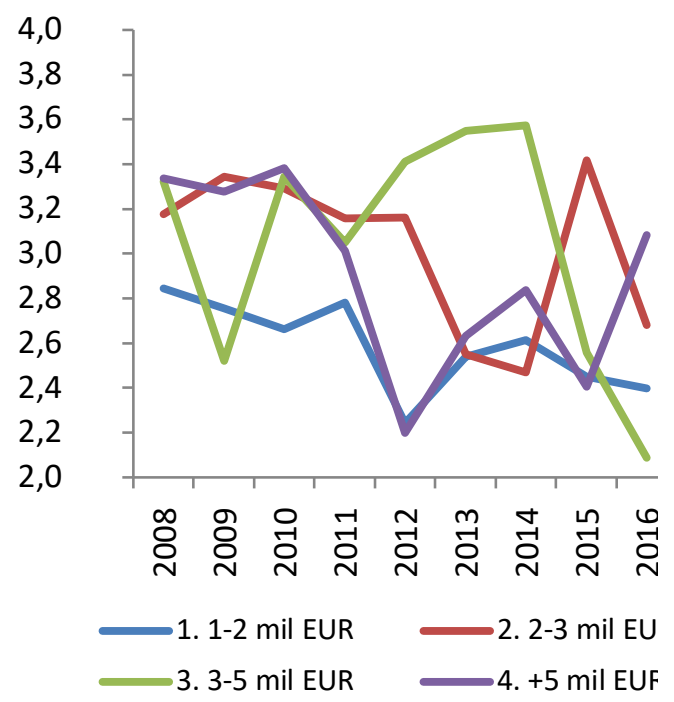


Ph.D. Student Rodica Baciu (Boanta), 2 Ph.D. Professor Brezeanu Petre, 3 Ph. D Lecturer Adrian Simon Insolvency Risk. Application of Altman Z-score to the auto parts sector in Romania

\begin{tabular}{|l|l|l|l|l|l|}
2014 & 2.62 & 2.47 & 3.57 & $\begin{array}{l}2.8 \\
4\end{array}$ & 2.82 \\
\hline 2015 & 2.45 & 3.42 & 2.56 & $\begin{array}{l}2.4 \\
1\end{array}$ & 2.45 \\
\hline 2016 & 2.40 & 2.68 & 2.09 & $\begin{array}{l}3.0 \\
8\end{array}$ & 2.89 \\
\hline
\end{tabular}

Source: Ministry of finance, data processed by the author

If we compare 2016 with the previous year, we observe a marginal improvement of the median Z-score value for all the companies in the appraised sector, from 2,45 (2015) to 2,89 (2016). This improvement is mostly due to increasing capitalization rate and less external debt, despite the deteriorating working capital (the current rate lowering from 1,76 in 2015 down to 1,43 in 2016) and operating margin (from $3 \%$ in 2015 down to $1,2 \%$ in 2016). If we consider the evolution for the entire appraised period and compare 2016 with 2008 , we observe a gradual deteriorating of the Z-score, mainly caused by lower operating margin, the latter decreasing from $7,8 \%$ in 2008 down to only $1,2 \%$ in 2016 . The Altman Zscore components are computed for each year and illustrated for all 168 appraised companies in the next two tables.

Table 6: Altman Z-score variables for all the appraised companies

\begin{tabular}{|l|r|r|r|r|r|l|}
\hline Year & \multicolumn{1}{|l|}{ X1 } & \multicolumn{1}{l|}{ X2 } & \multicolumn{1}{l|}{ X3 } & \multicolumn{1}{l|}{ X5 } & \multicolumn{1}{l|}{ Z-score Median } \\
\hline 2008 & 0.16 & 0.20 & 0.15 & 0.52 & 1.98 & 3.28 \\
\hline 2009 & 0.22 & 0.26 & 0.11 & 0.63 & 1.78 & 3.17 \\
\hline 2010 & 0.24 & 0.30 & 0.08 & 0.67 & 1.88 & 3.28 \\
\hline 2011 & 0.18 & 0.27 & 0.07 & 0.59 & 1.79 & 2.99 \\
\hline 2012 & 0.08 & 0.26 & 0.03 & 0.45 & 1.52 & 2.35 \\
\hline 2013 & 0.21 & 0.25 & 0.04 & 0.44 & 1.67 & 2.66 \\
\hline 2014 & 0.24 & 0.22 & 0.09 & 0.51 & 1.61 & 2.82 \\
\hline 2015 & 0.32 & 0.22 & 0.04 & 0.41 & 1.38 & 2.45 \\
\hline 2016 & 0.22 & 0.36 & 0.02 & 0.70 & 1.63 & 2.89 \\
\hline
\end{tabular}

Source: Ministry of finance, data processed by the author

Table 7: Financial ratios for all appraised companies

\begin{tabular}{|l|l|l|l|l|l|l|}
\hline Year & $\begin{array}{l}\text { Current Rate } \\
\text { (Current Assets / } \\
\text { Short Term Debt }\end{array}$ & $\begin{array}{l}\text { Equity Rate } \\
\text { (Equity / } \\
\text { Assets) }\end{array}$ & $\begin{array}{l}\text { Debt Rate } \\
\text { (Total Debt / } \\
\text { Assets) }\end{array}$ & $\begin{array}{l}\text { Turnover } \\
\text { (bn RON) }\end{array}$ & $\begin{array}{l}\text { EBIT : } \\
\text { Sales }\end{array}$ & $\begin{array}{l}\text { EAT : } \\
\text { Sales }\end{array}$ \\
\hline 2008 & 1.29 & 0.34 & 0.64 & 5.16 & $7.8 \%$ & $4.8 \%$ \\
\hline
\end{tabular}


Ph.D. Student Rodica Baciu (Boanta), 2 Ph.D. Professor Brezeanu Petre, 3 Ph. D Lecturer Adrian Simon Insolvency Risk. Application of Altman Z-score to the auto parts sector in Romania

\begin{tabular}{|l|l|l|l|l|l|l|}
2009 & 1.43 & 0.38 & 0.62 & 4.79 & $6.3 \%$ & $4.2 \%$ \\
\hline 2010 & 1.49 & 0.40 & 0.60 & 5.18 & $4.5 \%$ & $2.9 \%$ \\
\hline 2011 & 1.33 & 0.37 & 0.63 & 5.81 & $4.0 \%$ & $2.6 \%$ \\
\hline 2012 & 1.14 & 0.31 & 0.69 & 5.88 & $1.9 \%$ & $0.2 \%$ \\
\hline 2013 & 1.45 & 0.31 & 0.69 & 6.40 & $2.1 \%$ & $0.2 \%$ \\
\hline 2014 & 1.52 & 0.34 & 0.66 & 6.69 & $5.7 \%$ & $4.0 \%$ \\
\hline 2015 & 1.76 & 0.29 & 0.71 & 6.82 & $3.0 \%$ & $1.5 \%$ \\
\hline 2016 & 1.43 & 0.41 & 0.59 & 6.98 & $1.2 \%$ & $-0.4 \%$ \\
\hline
\end{tabular}

Source: Ministry of finance, data processed by the author

\section{Research Methodology}

The application of Altman Z-score over the selected sample of data, the followings steps were followed:

-all companies from the appraised sector (wholesale of motor vehicle parts and accessories, NACE 4531) with extended financial statements submitted for the entire appraised period were taken into consideration (to eliminate the survivorship effect). Since we need extended format of the financial statements, only companies with turnover above 1 mil EUR have been included, resulting a total number of 168 companies;

-the resulting companies were divided into four cross-sectional groups, depending on the turnover level: 1-2 mil EUR, 2-3 mil EUR, 3-5 mil EUR and +5 mil EUR;

The 5 variables of the Altman Z-score model have been computed for each cross-sectional group and year during the appraised period;

Since the regression equation contains both time series and cross-sectional data, a model with panel data was used, with 36 observations in total (9-time series and 4 cross-section data).

The model used is a multifactorial regression equation with fixed effects, to highlight the different profile of companies according to their turnover range. According to Gujarati (page 637), dummy variables that do not vary in time, but are different for each cross-sectional category (the 4 classes of companies according to the registered business figure) are to be used. Since the estimated values for the dummy variables are incidental (the difference from the cross-sectional series used as a reference), we will use a number of three dummy variables, the constant of the multifactor regression equation being the first class of companies. Thus, the multifactorial regression equation becomes:

$$
\begin{aligned}
& Z_{i t}=\alpha_{1}+\alpha_{2} * D_{2 i}+\alpha_{3} * D_{3 i}+\alpha_{4} * D_{4 i}+\beta_{2} * X 1_{i t}+\beta_{3} * X 2_{i t}+\beta_{4} * X 3_{i t}+\beta_{5} * X 4_{i t}+ \\
& \beta_{6} * X 5_{i t}+\mu_{i t}
\end{aligned}
$$

\section{Findings}


Ph.D. Student Rodica Baciu (Boanta), 2 Ph.D. Professor Brezeanu Petre, 3 Ph. D Lecturer Adrian Simon Insolvency Risk. Application of Altman Z-score to the auto parts sector in Romania

Applying the multifactor regression equation previously described on the data panel in EViews, we obtain the following result:

Dependent Variable: Z

Method: Least Squares

Date: 01/28/18 Time: 16:07

Sample: 136

Included observations: 36

\begin{tabular}{crlrr}
\hline \hline Variable & Coefficient & Std. Error & t-Statistic & Prob. \\
\hline \hline C & -0.018217 & 0.018809 & -0.968492 & 0.3414 \\
X1 & 1.250620 & 0.033260 & 37.60083 & 0.0000 \\
X2 & 1.428381 & 0.099343 & 14.37833 & 0.0000 \\
X3 & 3.499164 & 0.103421 & 33.83422 & 0.0000 \\
X4 & 0.602213 & 0.026592 & 22.64598 & 0.0000 \\
X5 & 0.984795 & 0.012015 & 81.96551 & 0.0000 \\
D1 & -0.007623 & 0.005730 & -1.330496 & 0.1945 \\
D2 & 0.001160 & 0.008571 & 0.135361 & 0.8933 \\
D3 & 0.018321 & 0.010286 & 1.781130 & 0.0861 \\
\hline \hline R-squared & 0.999488 & Mean dependent var & 2.892222 \\
Adjusted R-squared & 0.999336 & S.D. dependent var & 0.422043 \\
S.E. of regression & 0.010873 & Akaike info criterion & -5.992709 \\
Sum squared resid & 0.003192 & Schwarz criterion & -5.596829 \\
Log likelihood & 116.8688 & F-statistic & 6587.992 \\
Durbin-Watson stat & 2.453542 & Prob(F-statistic) & 0.000000 \\
\hline \hline
\end{tabular}

The same result is obtained by entering the cross-sectional observations and time series directly into the panel data model, namely:

Dependent Variable: Z?

Method: Pooled Least Squares

Date: 01/28/18 Time: 16:45

Sample: 19

Included observations: 9

Number of cross-sections used: 4

Total panel (balanced) observations: 36

\begin{tabular}{ccccc}
\hline \hline Variable & Coefficient & Std. Error & t-Statistic & Prob. \\
\hline \hline X1? & 1.250620 & 0.033260 & 37.60083 & 0.0000 \\
X2? & 1.428381 & 0.099343 & 14.37833 & 0.0000 \\
X3? & 3.499164 & 0.103421 & 33.83422 & 0.0000 \\
X4? & 0.602213 & 0.026592 & 22.64598 & 0.0000 \\
X5? & 0.984795 & 0.012015 & 81.96551 & 0.0000 \\
Fixed Effects & & & & \\
-01--C & -0.018217 & & & \\
-02--C & -0.025840 & & \\
-03--C & -0.017057 & & \\
-04--C & 0.000104 & & \\
\hline \hline R-squared & 0.999488 & Mean dependent var & 2.892222 \\
Adjusted R-squared & 0.999336 & S.D. dependent var & 0.422043 \\
S.E. of regression & 0.010873 & Sum squared resid & 0.003192 \\
Log likelihood & 116.8688 & F-statistic & 13175.98 \\
Durbin-Watson stat & 2.450712 & Prob(F-statistic) & 0.000000 \\
\hline \hline
\end{tabular}

This way the equation becomes:

$Z_{i t}=-0,0182-0,0258 * D_{2 i}-0,0170 * D_{3 i}-0,0001 * D_{4 i}+1,25 * X 1_{i t}+1,42 * X 2_{i t}+$ $3,49 * X 3_{i t}+0,60 * X 4_{i t}+0,98 * X 5_{i t}+\mu_{i t} ;$ where: 
Ph.D. Student Rodica Baciu (Boanta), 2 Ph.D. Professor Brezeanu Petre, 3 Ph. D Lecturer Adrian Simon Insolvency Risk. Application of Altman Z-score to the auto parts sector in Romania

$$
\begin{aligned}
& \alpha_{2}=\alpha_{1}-0,0076=-0,0182-0,0076=-0,0258 \\
& \alpha_{3}=\alpha_{1}+0,0011=-0,0182+0,0011=0,0170 \\
& \alpha_{4}=\alpha_{1}-0,0183=0,0182-0,0183=-0,0001
\end{aligned}
$$

\section{Interpretation:}

if $X 1$ (working capital /assets) raises with $100 \mathrm{bp}$, then the $Z$ score raises with $125 \mathrm{bp}$

if $\mathrm{X} 2$ (retained earnings /assets) raises with $100 \mathrm{bp}$, then the $Z$ score raises with $142 \mathrm{bp}$

if $\mathrm{X} 3$ (earnings before interest and tax /assets) raises with $100 \mathrm{bp}$, then the $\mathrm{Z}$ score raises with $349 \mathrm{bp}$

if $\mathrm{X} 4$ (equity /debt) raises with $100 \mathrm{bp}$, then the $Z$ score raises with $60 \mathrm{bp}$

if X5 (turnover /assets) raises with 100bp, then the $Z$ score raises with 98bp

A very important indicator that shows if the model is well-specified is R-squared. This indicates how many percent of the total dependent variable variance is explained by the independent variables using the following formula

R-squared $=($ TSS-SSE $) /$ TSS $=$ RSS $/$ TSS $=0,9994$

The higher the value of this indicator aims to 1, the better the model. In our case, $99.94 \%$ of the Z-score is explained by the five independent variables of the model.

The R-squared indicator increases as new independent variables are added to the multifactorial regression equation, but it also causes loss of degrees of freedom. Therefore, an adjusted measure of R-squared is better because it takes into account the number of independent variables included in the regression (Codarlasu and Ghidesciuc, pp. 44). The latter is calculated using the following formula:

$$
\bar{R}^{2}=1-\left(\frac{n-1}{n-k}\right) \cdot\left(1-R^{2}\right),
$$

\section{Where:}

$\mathrm{n}$ is the number of observations

$\mathrm{k}$ - the number of independent variables included in the regression

The E-Views results indicate a value of $99.93 \%$ for the adjusted R-squared coefficient, very close to that of the R-squared coefficient.

t-Test

To test if the estimated coefficients are relevant from the statistical point of view (different from zero), we can use the t-test, with the following assumptions:

$H_{0}: \beta_{1}=0$

$H_{1}: \beta_{1} \neq 0$

According to the E-Views results, the t-test value for the five exogenous (independent) variables, are presented next, using the previous formula: 
$t=\frac{\widehat{B}_{1}-\beta_{0}}{\operatorname{se}\left(\widehat{乃}_{1}\right)}=\frac{1,2506-0}{0,03336}=37,6008($ for $\mathrm{X} 1)$

$t=\frac{\widehat{乃}_{2}-\beta_{0}}{\operatorname{se}\left(\widehat{乃}_{2}\right)}=\frac{1,428381-0}{0,099343}=14,3783($ for $\mathrm{X} 1)$

$t=\frac{\widehat{\mathrm{S}}_{3}-\beta_{0}}{\operatorname{se}\left(\widehat{\mathrm{S}}_{3}\right)}=\frac{3,49916-0}{0,10342}=33,8342($ for $\mathrm{X} 1)$

$t=\frac{\widehat{B}_{4}-\beta_{0}}{\operatorname{se}\left(\widehat{\mathbb{B}}_{4}\right)}=\frac{0,6022-0}{0,02659}=22,6459($ for $\mathrm{X} 1)$

$t=\frac{\widehat{乃}_{5}-\beta_{0}}{\operatorname{se}\left(\widehat{\aleph}_{5}\right)}=\frac{0,98479-0}{0,01201}=81,9655($ for $\mathrm{X} 1)$

Considering that the probability associated with the lower relevant level employed (5\%), then the null hypothesis is rejected and the coefficient is considered to be significant statistically. This can be verified with the fact that the displayed value of the t-test is above the critical value. The latter, can be calculated using the following formula: $t_{c}=\frac{t_{\overline{2}} ; n-m}{} ;$ where a represents the relevance level $(5 \%)$ divided by 2 (because the test checks if the estimated value is equal or different form 0 ), $\mathrm{n}$ represents the observations number(36), and $\mathrm{m}$ represents the number of estimated parameters (9). So the $t_{0,025 ; 27}$ value is approximately 2,052 . Because $t$ values for all the five independent variables are above the Tc $(2,052)$, the null hypothesis is rejected. Instead, the likelihood associated with the constants for all dummy variables (corresponding to each group of companies according to turnover) is above the relevant level $(5 \%)$, which implies that the null hypothesis is accepted and the coefficient isn't statistically significant, (not different from zero value). This is consistent to our expectations, indicating the Z-score formula is valid for all companies, regardless the turnover range.

F-test

This test indicates to what extent a set of independent variables explains, as a group, the variation of the dependent variable, and determines the extent to which all coefficients of the regression equation simultaneously have zero values. The hypotheses are:

$H_{0}: \beta_{1}=\beta_{2}=\beta_{3}=\beta_{4}=\beta_{5}=0$,

$H_{1}: \beta_{1} \neq \beta_{2} \neq \beta_{3} \neq \beta_{4} \neq \beta_{5} \neq 0$,

The value of the F-test calculated by E-views is close to 6588 and is obtained using the formula:

$F=\frac{\frac{R^{2}}{m-1}}{\frac{1-R^{2}}{n-m}}=\frac{\frac{0,9994}{9-1}}{\frac{1-0,9994}{36-9}}=6587,99$

The $\mathrm{F}$ test follows a distribution $\mathrm{F}$, and the critical value is determined as follows: $F_{c}=$ $F_{\alpha ; m-1 ; n-m}=F(0,05 ; 8 ; 27)=5,28$. Since the calculated value $(6588)$ is higher than the critical value $(5,28)$, then the null hypothesis is rejected, which means that at least one of the coefficients of the regression equation is statistically significant. The same conclusion is reached if we observe that the associated probability is inferior to the level of relevance to which it is being worked (5\%). 


\section{Conclusion and Recommendations}

Altman Z-score model is a multiple regression analysis, becoming very famous due to it's simplicity for both understanding and practical use. Based on this model, the Z-score is computed by using both balance sheet (working capital, capital structure) and income statement elements (turnover, earnings before interest and tax). In this paper, we apply the Altman Z-score for to all the companies active in the wholesale of motor vehicle parts and accessories, NACE 4531, with extended financial statements submitted for the entire appraised period were taken into consideration (to eliminate the survivorship effect). Since we need extended format of the financial statements, only companies with turnover above 1 mil EUR have been included, resulting a total number of 168 companies. Since the regression equation contains both time series and cross-sectional data, a model with panel data was used, with 36 observations in total (9-time series for the period 2008-2016 and 4 cross-section data with different clusters depending on revenues: 1-2 mil EUR, 2-3 mil EUR, 3-5 mil EUR and +5 mil EUR). The results generated with E-views are very close to the parameters from the original model. According to the R-squared estimated value from the model, $99,94 \%$ from the evolution of the Z-score is explained by the independend variabiles (working capital, retained earnings, earnings before interest and tax, equity and turnover).

Given the overall concentration of revenues among the largest companies in the overall business environment and the selected list of companies, the sample is divided in four different clusters by turnover level, that represent the cross-sectional series in the panel data model described in the methodology. The Z-score for the selected companies is computed for the entire appraised period (2008-2016) and the evolution illustrates a tendency for decreasing high risk companies (from 25 in 2008 down to 15 in 2016) and increase in the medium risk companies (from 43 in 2008 to 56 in 2016), whereas the low risk companies are relatively stable. The overall Z-score has marginally decreased for most of the clusters, with the largest companies ( +5 mil EUR turnover) performing the best according the Altman Z-score (median value above 3). If we compare 2016 with the previous year, we observe a marginal improvement of the median Z-score value for all the companies in the appraised sector, from 2,45 (2015) to 2,89 (2016). This improvement is mostly due to increasing capitalization rate and less external debt, despite the deteriorating working capital (the current rate lowering from 1,76 in 2015 down to 1,43 in 2016) and operating margin (from $3 \%$ in 2015 down to 1,2\% in 2016). If we consider the evolution for the entire appraised period and compare 2016 with 2008, we observe a gradual deteriorating of the Z-score, mainly caused by lower operating margin, the latter decreasing from $7,8 \%$ in 2008 down to only $1,2 \%$ in 2016

Future research to evaluate Z-score sensitivity under stress test scenarios would be very useful to provide an insight of companies insolvency risk amid increasing interest rates and different fiscal tax on dividend. This is very necessary especially given the very unpredictable fiscal environment in Romania. The pro-cyclical fiscal measures cause GDP growth to reach $7 \%$ during 2017 in Romania, significantly above the potential level of $3 \%-3,5 \%$. This is fueling increasing inflationary pressure, steaming to almost $5 \%$ during the first semester of 2018 and 3,2\% Central Bank of Romania latest estimate for 2018 full year. That will force the Central Bank to launch an restrictive pace of the monetary policy, already visible with monetary rate hike from $1,75 \%$ to $2 \%$ during January 2018 . Under this context, increasing financial burden of companies with translate in lower operating margins. Moreover, the proposal of dividend tax cut down to zero starting 2019 (according to the latest government plan) would motivate shareholders to distribute profits as dividends and lower the retained earnings, Both factors will negatively impact the Z-score results for the companies active in Romania.

\section{References}


- Altman, E. I. (2000). Predicting financial distress of companies: revisiting the Zscore and ZETA models. Stern School of Business, New York University, 9-12.

- Codarlasu, A. si Ghidesciuc, N, (2008), Applied Econometrics, pp.44-55

- Chouhan, V., Chandra, B. and Goswami, S. (2014). Predicting Financial Stability of Select BSE Companies Revisiting Altman Z Score. ILSHS, 26, pp.92-105. Crossref

- Iqbal, A. and Zhuquan, W. (2015). Working Capital Management and Profitability Evidence from Firms Listed on Karachi Stock Exchange. International Journal of Business and Management, 10(2), pp.25-40. Crossref

- Khajavi, S. and Ghoohestani, S. (2015). The Effects of Cash Flow Uncertainty and Working Capital on Non-Cash Flow Shock Returns. International Business Research, 8(4), pp. 115-121. Crossref

- Koussis, N., Martzoukos, S. and Trigeorgis, L. (2017). Corporate liquidity and dividend policy under uncertainty. Journal of Banking \& Finance, 81, pp.221-235. Crossref

- Royer, J. (2017). Financing agricultural cooperatives with retained earnings. Agricultural Finance Review, 77(3), pp.393-411. Crossref

- Singhania, M. and Mehta, P. (2017). Working capital management and firms' profitability: evidence from emerging Asian countries. South Asian Journal of Business Studies, 6(1), pp.80-97. Crossref

- Turner, J. (2016). Net Operating Working Capital, Capital Budgeting, And Cash Budgets: A Teaching Example. American Journal of Business Education (AJBE), 9(1), pp. 31-62. Crossref

- Tian, S. and Yu, Y. (2017). Financial ratios and bankruptcy predictions: An international evidence. International Review of Economics \& Finance, 51, pp.510526. $\underline{\text { Crossref }}$

- Wu, Y., Yang, J. and Zou, Z. (2017). Dynamic corporate investment and liquidity management under model uncertainty. Economics Letters, 155, pp.9-23. Crossref 